$$
\text { cons- } 9510294-2
$$

DOE/METC/C-96/7214

A Reduced Mechanism for Low-Heating-Value Gas Combustion in a Perfectly Stirred Reactor

Authors:

David Marlow

Thomas S. Norton

Conference Title:

American Flame Research Committee 1995 International Symposium

Conference Location:

Monterey, California

RECEIVED

FEB 131935

OSTI

Conference Dates:

October 15-18, 1995

Conference Sponsor:

International Flame Research Foundation 


\section{DISCLAIMER}

This report was prepared as an account of work sponsored by an agency of the United States Government. Neither the United States Government nor any agency thereof, nor any of their employees, makes any warranty, express or implied, or assumes any legal liability or responsibility for the accuracy, completeness, or usefulness of any information, apparatus, product, or process disclosed, or represents that its use would not infringe privately owned rights. Reference herein to any specific commercial product, process, or service by trade name, trademark, manufacturer, or otherwise does not necessarily constitute or imply its endorsement, recommendation, or favoring by the United States Government or any agency thereof. The views and opinions of authors expressed herein do not necessarily state or reflect those of the United States Government or any agency thereof.

This report has been reproduced directly from the best available copy.

Available to DOE and DOE contractors from the Office of Scientific and Technical Information, 175 Oak Ridge Turnpike, Oak Ridge, TN 37831; prices available at (615) 576-8401.

Available to the public from the National Technical Information Service, U.S. Department of Commerce, 5285 Port Royal Road, Springfield, VA 22161; phone orders accepted at (703) 487-4650. 


\title{
A REDUCED MECHANISM FOR LOW-HEATING-VALUE GAS COMBUSTION IN A PERFECTLY STIRRED REACTOR
}

\author{
D. Marlow* and T. S. Norton \\ Department of Energy \\ Morgantown Energy Technology Center \\ Morgantown, WV 26505
}

We have begun an effort to accurately model $\mathrm{NO}_{x}$ formation from the combustion of coal-derived fuels in turbine combustors. Both turbulent mixing and the chemical kinetics of ammonia oxidation are expected to have important influences upon $\mathrm{NO}_{\mathrm{x}}$ formation rates. This paper concentrates upon the development of a model for the kinetics. Previous empirical, kinetic mechanisms have inaccurately assumed equilibrium $\mathrm{OH}$ concentrations and ignored the chemistry of $\mathrm{HCN}$, an important intermediate. We have developed a reduced mechanism by applying simplifying assumptions to a full, detailed mechanism for methane combustion with nitrogen chemistry. The mechanism contains 7 rates for 10 non-steady-state species, a single partial equilibrium assumption, and steady-state relations for 18 species. The Zeldovich and Fenimore mechanisms of NO formation are modeled, as is the NO recycle mechanism by which NO is converted to $\mathrm{HCN}$. Nitric oxide formation from $\mathrm{N}_{2} \mathrm{O}$ is also included. Two oxidation routes for $\mathrm{NH}_{3}$ are included: the first describes $\mathrm{NH}_{3}$ conversion to $\mathrm{N}$, and then to $\mathrm{NO}$; the second describes HNO formation, and final conversion of $\mathrm{HNO}$ to NO. Stirred reactor calculations were performed for three cases: (1) methane-air combustion with no nitrogenated species in the reactants, (2) methane-air combustion with $1000 \mathrm{ppmV} \mathrm{NO}$ in the reactants, and (3) methane-air combustion with $1000 \mathrm{ppmV} \mathrm{NH}_{3}$ in the reactants. The reactor temperature (1300 to $2000 \mathrm{~K}$ ) and residence time $\left(10^{-4}\right.$ to $\left.10^{-1} \mathrm{~s}\right)$ were varied. Both the reduced and skeletal mechanism calculations agree very well with calculations using the detailed mechanism of Miller and Bowman, except for fuel-rich combustion at low temperatures (less than $1500 \mathrm{~K}$ ), where results from the skeletal mechanism begin to deviate due to neglect of $\mathrm{C}_{2}$ chemistry. Future work will test the performance of the reduced and skeletal mechanisms in models of laminar, counterflow flames, which are meant to represent flamelet combustion in a turbulent flame.

\section{Introduction}

Our goal is to properly model the production of $\mathrm{NO}_{\mathrm{x}}$ from $\mathrm{NH}_{3}$ during the combustion of lowheating-value gas in industrially relevant flames. We are most interested in the flames in turbine combustors as implemented in coal-gas-fueled combined cycle systems. These flames are premixed or mostly premixed, pressurized, and turbulent.

Turbulent flame modelers frequently neglect the chemical kinetics of fuel conversion because the fuel consumption reactions occur in thin spatial regions, rapidly converting the reactants to their equilibrium state. Ammonia in the fuel is also consumed rapidly in thin spatial regions; however, ammonia is typically not converted to its equilibrium products. The fractions of $\mathrm{NO}, \mathrm{N}_{2}$, and $\mathrm{HCN}$ formed depend strongly upon kinetics. Relative production rates of these species vary

*NRC Resident Research Associate 
greatly with varying equivalence ratio, flame residence time, temperature, and hydrocarbon concentration in the fuel. Since $\mathrm{NH}_{3}$ oxidation is sensitive to the kinetics and the kinetics is in turn sensitive to the flame environment, a kinetic mechanism should be incorporated to accurately model $\mathrm{NO}_{\mathrm{x}}$ formation in turbulent flames.

A simple, empirical kinetic mechanism for $\mathrm{NH}_{3}$ conversion has been included previously in a model of a turbulent, jet flame (Drake et al., 1984). The mechanism contains two global reactions to form $\mathrm{NO}$ and $\mathrm{N}_{2}$. Formation of $\mathrm{HCN}$ is not considered. The global rates are written as the products of Arrhenius coefficients, the $\mathrm{NH}_{3}$ concentration, and the equilibrium $\mathrm{OH}$ concentration. The jet is modeled for a low turbulent Reynolds number and varying $\mathrm{NH}_{3}$ concentration. Predictions and measurements for the jet show similar trends with varying $\mathrm{NH}_{3}$ concentration, but the predicted $\mathrm{NO}_{\mathrm{x}}$ emissions are consistently $50 \%$ greater than measured.

Several assumptions made by Drake et al. probably limit both the accuracy and range of applicability of their empirical mechanism. First, neglect of HCN chemistry should cause inaccuracies for all but lean, premixed combustion, since $\mathrm{HCN}$ is frequently important as both an intermediate and a product of $\mathrm{NH}_{3}$ conversion for fuel-rich conditions. Hydrogen cyanide is especially important as a product of rich-stage combustion in a two-stage reactor since the HCN created in the first stage is converted to $\mathrm{NO}$ in the second stage. Second, though the equilibrium $\mathrm{OH}$ concentration has been applied in the rate calculations, we cannot expect to be able to correlate $\mathrm{NH}_{3}$ conversion with an equilibrium $\mathrm{OH}$ concentration over the entire flame. Instantaneous data from laser-based experiments (Barlow and Carter, 1994) indicate that the region of a jet flame near its tip is nearly equilibrated at the state defined by the instantaneous mixture fraction. However, near the nozzle flamelet-like behaviour occurs, resulting in $\mathrm{OH}$ concentrations far from equilibrium. More detailed descriptions of both the nitrogen and hydrocarbon oxidation kinetics are needed, especially to accurately model the influence of nonequilibrium radical concentrations on $\mathrm{NO}_{x}$ conversion.

Though rates and minor pathways may still be controversial, the detailed kinetic mechanism for low-heating-value gas combustion is well understood at atmospheric pressure. However, due to computational limitations the full mechanism cannot be used for industrially relevant flames. Peters (1991) has developed a method for reducing the detailed mechanism. First, reactions are eliminated from the full, detailed mechanism to create the minimum possible reaction set (called a skeletal mechanism) capable of accurately modeling the system of interest. Then partialequilibrium and steady-state assumptions are applied to create algebraic expressions for shortlived intermediates, and global reactions are formulated for the remaining non-steady state species. Because reduced mechanisms are simplifications of detailed mechanisms, they provide computationally tractable models that are more closely representative of the full chemistry than empirical, global rates.

Several researchers are actively developing reduced mechanisms for $\mathrm{NO}_{\mathrm{x}}$ formation. Chung and Lee (1993) have modeled laminar, counterflow diffusion flames of natural gas. Only the 
Zeldovich mechanism for NO formation is considered in their calculations. Glarborg et al. (1992) have considered methane combustion in a perfectly-stirred reactor. The Glarborg reduced mechanism includes the Fenimore and Zeldovich pathways, $\mathrm{HCN}$ oxidation, and the NO recycle mechanism to reduce NO to $\mathrm{HCN}$. Lindstedt and Selim (1994) have accurately modeled $\mathrm{NH}_{3}$ oxidation in premixed flames of hydrogen and air. The allowed pathways to $\mathrm{NO}_{\mathrm{x}}$ formation are $\mathrm{NH}_{3}$ destruction and the Zeldovich mechanism. Of these efforts, the work by Glarborg et al. comes closest to incorporating all of the reactions necessary to model low-heating-value gas combustion. However, we cannot directly apply the Glarborg mechanism because $\mathrm{NH}_{3}$ oxidation is not included. The Lindstedt mechanism does include $\mathrm{NH}_{3}$ oxidation, but does not include carbon-containing species. Current mechanisms must be extended or combined.

We have adapted the work of Lindstedt and Glarborg to create a "combined" reduced mechanism for low-heating-value gas combustion. Our skeletal mechanism contains all the reactions of the Glarborg skeletal mechanism, with 20 reactions added to this set to model $\mathrm{NH}_{3}$ chemistry. Glarborg's steady-state equations are rederived to account for the added reactions, and three new steady-state equations are introduced for three species added to the system by the new reactions. The resulting reduced mechanism has 7 reaction rates for 10 non-steady state species and 18 steady-state and partial-equilibrium equations.

The model is tested for a wide range of conditions in a perfectly stirred reactor (PSR). The PSR is chosen as a well-defined representation of the distributed reaction zones observed in turbulent flames. Future work will consider another environment characteristic of turbulent flames, namely, flamelet combustion.

The next section defines the skeletal mechanism. Following this the reduced mechanism is derived. Then the mechanism is validated against skeletal and detailed calculations for a wide range of conditions in the PSR.

\section{Skeletal Mechanism}

The skeletal mechanism is shown in Table I. The first 77 reactions in the table are taken directly from Glarborg et al. (1992) The rates of these reactions are based on a full detailed mechanism of Glarborg (unpublished), which is an update of the mechanism published by Miller and Bowman. The remaining 20 reactions of Table I are added based on the work of Lindstedt and Selim, with rate coefficients from Miller and Bowman. Figures 1 through 6 contain curves calculated with: (1) the reduced mechanism derived in the next section, (2) the skeletal mechanism of Table I, and (3) the detailed mechanism of Miller and Bowman, with the rate for the reaction, $\mathrm{CH}+\mathrm{N}_{2}=\mathrm{HCN}+\mathrm{N}$, taken from the more recent measurements of Dean et al. (1990). The mechanism of Miller and Bowman is used for comparison in this study because of its ready availability and general acceptance. 
The greatest difference between the detailed mechanism and the skeletal mechanism is the neglect of the chemistry of $\mathrm{C}_{2}$ and higher hydrocarbons in the skeletal mechanism. The $\mathrm{C}_{2}$ chemistry has a secondary effect on $\mathrm{NO}_{\mathrm{x}}$ kinetics through the formation of soot and soot precursors, which lower the temperature and decrease $\mathrm{NO}_{\mathrm{x}}$ formation through the thermally sensitive Zeldovich mechanism. The only direct effect of $\mathrm{C}_{2}$ chemistry on $\mathrm{NO}_{\mathrm{x}}$ kinetics occurs through the reaction, - $\mathrm{HCCO}+\mathrm{NO}=\mathrm{HCNO}+\mathrm{CO}$, which is an important path to reduce NO to $\mathrm{HCN}$ and $\mathrm{N}_{2}$ at lowtemperature, fuel-rich conditions. The reactions associated with $\mathrm{NO}_{2}$ formation and destruction in the skeletal mechanism are also neglected since $\mathrm{NO}_{2}$ emissions are insignificant in this study.

For low-heating-value gas combustion at typical operating conditions, most of the $\mathrm{NO}_{\mathrm{x}}$ formation results from $\mathrm{NH}_{3}$ oxidation. The chief path for $\mathrm{NH}_{3}$ conversion is through the nitrogen atom. Ammonia is converted to $\mathrm{N}$ by reaction with $\mathrm{H}, \mathrm{O}$, and $\mathrm{OH}$. The resulting $\mathrm{N}$ then participates in the reactions of the extended Zeldovich mechanism. In the absence of ammonia, $\mathrm{N}$ is chiefly produced through the rate-limiting Zeldovich reaction:

$$
N_{2}+O=N+N O
$$

Another less important but generally significant path from $\mathrm{NH}_{3}$ to $\mathrm{NO}$ is through $\mathrm{HNO}$ :

$$
\mathrm{NH}_{3} \rightarrow \mathrm{NH}_{2} \rightarrow \mathrm{HNO} \rightarrow \mathrm{NO}
$$

Again, this path occurs by reactions with $\mathrm{O}, \mathrm{H}$, and $\mathrm{OH}$.

Ammonia can also play a very important role in reducing NO through the paths:

$$
\begin{aligned}
& \mathrm{NH}_{2}+N \mathrm{NO} \rightarrow \mathrm{N}_{2}+\ldots \\
& N H_{2}+N O \rightarrow N N H+N O \\
& N N H+N O \rightarrow N_{2}+H N O
\end{aligned}
$$

The remaining $\mathrm{HNO}$ is also reduced to molecular nitrogen through the path,

$$
H N O \rightarrow N H \rightarrow N \rightarrow N_{2}
$$

All of these paths are brought about by reactions with $\mathrm{O}, \mathrm{H}, \mathrm{OH}$, and $\mathrm{N}$-species. No hydrocarbon species (in fact, no carbon containing species) participates in any of the reaction pathways discussed thus far.

When hydrocarbons are present, another important route to NO production and destruction occurs 
through HCN. Production of NO occurs via the Fenimore mechanism chiefly by the pathway:

$$
\mathrm{CH}+\mathrm{N}_{2} \rightarrow H C N \rightarrow N C O \rightarrow N H \rightarrow N \rightarrow N O
$$

In the absence of oxygen, the $\mathrm{HCN}$ is not oxidized to NO, but remains as a stable product. For more fuel rich situations, recycle of $\mathrm{NO}$ to $\mathrm{HCN}$ and $\mathrm{N}_{2}$ becomes important:

$$
\mathrm{NO}+\mathrm{CH} \rightarrow \mathrm{HCN} \rightarrow \mathrm{N}_{2}
$$

This pathway causes the reduction of NO observed in reburning.

Our domain of interest also includes low-temperature, fuel-lean combustion. Under these conditions, the $\mathrm{N}_{2} \mathrm{O}$ mechanism for NO formation becomes significant:

$$
N_{2}+O+M \rightarrow N_{2} O \rightarrow N O
$$

\section{Reduced Mechanism}

The skeletal mechanism is reduced to seven rate equations by applying partial equilibrium and steady state assumptions. Application of the steady-state assumption here assumes that the change in concentration from a species' initial value is small relative to the rates of production and destruction. The assumption leads to an algebraic expression for the concentration of the steady-state species. Since there are no derivatives in the conservation equations for the PSR, the equations for all species are algebraic equations, and little or no reduction in computational effort results from the steady-state assumptions. When convection and diffusion are important to a problem, finite differencing is applied. Then the steady-state assumption decouples the species equations for each node, resulting in significant simplifications to the numerical problem.

The following species are assumed in steady state: $\mathrm{O}, \mathrm{CH}_{3},{ }^{3} \mathrm{CH}_{2},{ }^{1} \mathrm{CH}_{2}, \mathrm{CH}_{2} \mathrm{OH}, \mathrm{CH}_{2} \mathrm{O}, \mathrm{CH}$, $\mathrm{HCO}, \mathrm{C}, \mathrm{HO}_{2}, \mathrm{CN}, \mathrm{NCO}, \mathrm{NH}, \mathrm{N}, \mathrm{N}_{2} \mathrm{O}, \mathrm{NH}_{2}, \mathrm{NNH}, \mathrm{HNO}$. The first 15 of these were assumed in steady-state by Glarborg et al. (1992). The last three species are added here for $\mathrm{NH}_{3}$ conversion. In addition, $\mathrm{OH}$ is assumed in partial equilibrium. The steady-state assumptions for the first 15 species listed above have been tested thoroughly for combustion in a PSR by Glarborg et al. (1992), as has the partial equilibrium assumption for $\mathrm{OH}$. The validity of the steady-state assumptions for the 3 remaining species $\left(\mathrm{NH}_{2}, \mathrm{NNH}, \mathrm{HNO}\right)$ has been established in low-pressure, premixed flames by Lindstedt et al. The validity of these assumptions for PSR conditions is established by the agreement between the skeletal and reduced mechanisms observed 
below.

Many of the steady-state equations derived originally by Glarborg et al. remain unchanged by our additions to the skeletal mechanism. However, they will be repeated here to avoid propagating errors. The partial equilibrium relation for $\mathrm{OH}$ is:

$$
[\mathrm{OH}]=\frac{k_{b 3}\left[\mathrm{H}_{2} \mathrm{O}\right][\mathrm{H}]}{k_{f 3}\left[\mathrm{H}_{2}\right]}
$$

The steady-state assumptions are:

$$
[O]=\frac{\sqrt{B^{2}-4 A C}-B}{2 A}
$$

where,

$$
\begin{gathered}
A=k_{f 16}\left(N_{O}+k_{f 11}\left[C H_{4}\right]\right) \\
B=N_{O} N_{C H_{3}}-k_{f 16}\left(\omega_{f 1}+\omega_{b 2}+\omega_{f 4}-\omega_{f 10}-\omega_{f 12}\right) \\
C=N_{C H_{3}}\left(\omega_{f 1}+\omega_{b 2}+\omega_{f 4}\right) \\
N_{C H_{3}}=k_{b 10}\left[H_{2}\right]+k_{b 12}\left[H_{2} O\right]+k_{f 13}[H]+\left(k_{b 18}+k_{b 19}\right)[O H] \\
{\left[C H_{3}\right]=\frac{N_{O}=k_{b 1}[O H]+k_{f 2}\left[H_{2}\right]+k_{b 4}\left[H_{2} O\right]+k_{f 11}\left[C H_{4}\right]}{k_{b 10}\left[H_{2}\right]+k_{b 12}\left[H_{2} O\right]+k_{f 13}[H]+k_{f 16}[O]+\left(k_{b 18}+k_{b 19}\right)[O H]}} \\
\omega_{f 10}+\omega_{f 11}+\omega_{f 12}
\end{gathered}
$$




$$
\begin{aligned}
& {\left[{ }^{3} \mathrm{CH}_{2}\right]=\frac{\omega_{f 14}+\omega_{f 17}+S_{39}\left(\omega_{b 15}+\omega_{b 18}\right)}{N_{.{ }^{3} \mathrm{CH}_{2}}-S_{39} k_{b 39}[M]}} \\
& S_{39}=\frac{k_{f 39}[M]}{N_{.1}{ }^{1} \mathrm{CH}_{2}} \\
& N_{.{ }^{1} \mathrm{CH}_{2}}=k_{f 15}\left[\mathrm{H}_{2}\right]+k_{f 18}\left[\mathrm{H}_{2} \mathrm{O}\right]+k_{f 39}[\mathrm{M}]+k_{f 40}\left[\mathrm{O}_{2}\right]+k_{f 41}\left[\mathrm{CO}_{2}\right] \\
& N_{.{ }^{3} \mathrm{CH}_{2}}=k_{b 14}\left[H_{2}\right]+k_{b 17}\left[H_{2} O\right]+\left(k_{f 31}[M]+k_{f 32}\right)[H] \\
& +\left(k_{f 33}+k_{f 34}\right)[N O]+\left(k_{f 35}+k_{f 36}\right)[O H] \\
& +\left(k_{f 37}+k_{f 38}\right)\left[O_{2}\right]+k_{b 39}[M] \\
& {\left[{ }^{1} \mathrm{CH}_{2}\right]=\frac{\omega_{b 15}+\omega_{b 18}+\omega_{b 39}}{N_{.1}{ }^{1} \mathrm{CH}_{2}}} \\
& {\left[\mathrm{CH}_{2} \mathrm{OH}\right]=\frac{\omega_{b 19}+\omega_{f 20}}{k_{f 19}[H]+k_{f 23}[M]+k_{f 24}\left[\mathrm{O}_{2}\right]}} \\
& {\left[\mathrm{CH}_{2} \mathrm{O}\right]=\frac{\omega_{f 16}+\omega_{f 23}+\omega_{f 24}+\omega_{f 35}+\omega_{f 37}+\omega_{f 41}+\omega_{f 47}}{k_{f 25}[H]+k_{f 26}[O H]}} \\
& {[C H]=\frac{\omega_{f 32}+\omega_{f 36}}{N_{C H}-\left(S_{42}+S_{45}\right)\left(k_{f 42}[H]+k_{f 45}[O H]\right)}}
\end{aligned}
$$




$$
\begin{aligned}
& N_{C H}=k_{b 32}\left[H_{2}\right]+k_{b 36}\left[H_{2} O\right]+k_{f 42}[H]+k_{f 43}[N O]+\left(k_{f 44}+k_{f 45}\right)[\mathrm{OH}] \\
& +k_{f 46}\left[\mathrm{O}_{2}\right]+k_{f 47}\left[\mathrm{H}_{2} \mathrm{O}\right]+k_{f 48}\left[\mathrm{CO}_{2}\right] \\
& S_{42}=\frac{k_{b 42}\left[H_{2}\right]}{N_{C}} \\
& {[C]=\frac{\omega_{f 42}+\omega_{f 45}}{N_{C}}} \\
& S_{45}=\frac{k_{b 45}\left[H_{2} O\right]}{N_{C}} \\
& N_{C}=k_{b 42}\left[H_{2}\right]+k_{b 45}\left[H_{2} O\right]+k_{f 49}[O H]+k_{f 50}\left[O_{2}\right] \\
& {[H C O]=\frac{\omega_{f 25}+\omega_{f 26}}{k_{f 22}\left[\mathrm{CH}_{3}\right]+k_{f 27}[M]+k_{f 28}[H]+k_{f 29}[\mathrm{OH}]+k_{f 30}\left[\mathrm{O}_{2}\right]}} \\
& {\left[\mathrm{HO}_{2}\right]=\frac{\omega_{f 6}+\omega_{f 24}+\omega_{f 30}}{k_{f 7}[H]+k_{f 8}[\mathrm{OH}]+k_{f 21}\left[\mathrm{CH}_{3}\right]}} \\
& {[C N]=\frac{\omega_{f 62}+\omega_{f 70}+\omega_{f 74}}{k_{b 62}\left[H_{2} O\right]+k_{f 64}[O H]+k_{f 65}\left[O_{2}\right]}} \\
& {[N C O]=\frac{\omega_{f 60}+\omega_{f 63}+\omega_{f 64}+\omega_{f 65}}{k_{f 66}[H]+k_{f 67}[O H]+k_{f 68}[N O]}}
\end{aligned}
$$




$$
\begin{aligned}
& { }^{969} \mathrm{~m}+{ }^{269} \mathrm{~m}+{ }^{069} \mathrm{~m}+{ }^{589} \mathrm{~m}+{ }^{789} \mathrm{~m}+ \\
& { }^{88 q} m_{+}{ }^{289} m+{ }^{28 q} m+{ }^{087} m+{ }^{6 L I} m+{ }^{8 L 7} m={ }^{2 H N} \Omega \\
& \frac{{ }^{z_{H N}}}{{ }^{{ }_{H N}} \Omega}=\left[{ }^{z} H N\right] \\
& { }^{987} m_{+}{ }^{5 L F} m_{+}{ }^{0 \angle F} m_{+}{ }^{697} m_{+} \angle S q m_{+}{ }^{9 S q} m_{+}{ }^{5 S q} m_{+} \text {ESF } m_{+}{ }^{\text {ISF }} m={ }^{N} n \\
& {\left[O^{z} H\right]^{98 q} X+\left[{ }^{\varepsilon} H D\right]^{\angle L F} X+\left[{ }^{z} O D\right]^{9 \angle F} X+} \\
& {[O N]^{L S \exists} Y+\left[{ }^{z} O\right]^{9 S F} X+\left[{ }^{Z} H\right]{ }^{I S q} Y+[H O]\left({ }^{S S I} Y+{ }^{\varepsilon S q} Y\right)={ }^{N} N} \\
& \frac{N_{N}}{N_{\Omega}}=[N]
\end{aligned}
$$

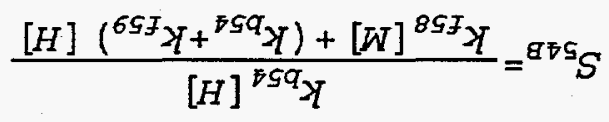

$$
\begin{aligned}
& \left({ }^{897} m+{ }^{85 q} m\right)^{875} S+{ }^{26 q} m_{+}{ }^{88 q} m_{+}{ }^{28 q} m+{ }^{98 q} m+{ }^{887} m+{ }^{287} m+ \\
& { }^{287} m+{ }^{997} m+{ }^{I 97} m+{ }^{\varepsilon S q} m+{ }^{25 q} m+{ }^{I S q} m={ }^{H N} \Omega
\end{aligned}
$$

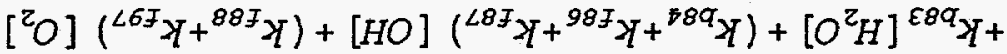

$$
\begin{aligned}
& {\left[{ }^{Z} H\right]{ }^{Z 89} Y+[O N]\left({ }^{B S I} Y+{ }^{E S I} Y+{ }^{Z S F} Y\right)+[H]{ }^{I S I} Y={ }^{H N} N}
\end{aligned}
$$

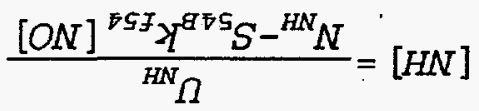

UOHON S I pUE MOIIEN G 


$$
\begin{aligned}
N_{N H_{2}} & =k_{f 81}[H]+k_{b 78}\left[H_{2}\right]+k_{b 79}\left[H_{2} O\right]+\left(k_{b 80}+k_{f 82}\right)[O H] \\
& +\left(k_{f 83}+k_{f 84}\right)[N O]+\left(k_{f 85}+k_{f 92}\right)[N O]+k_{f 90}[N N H]+k_{f 96}[H N O]
\end{aligned}
$$

$$
\begin{gathered}
{\left[N_{2} O\right]=\frac{\omega_{f 54}+\omega_{b 58}+\omega_{f 68}+\omega_{b 59}}{k_{f 58}[M]+\left(k_{b 54}+k_{f 59}\right)[H]}} \\
{[N N H]=\frac{\omega_{b 89}+\omega_{b 90}+\omega_{b 91}+\omega_{f 92}}{k_{f 90}\left[N H_{2}\right]+k_{f 91}[N O]+\left(k_{f 89}+k_{b 92}\right)[O H]}} \\
{[H N O]=\frac{\omega_{f 84}+\omega_{f 87}+\omega_{f 91}+\omega_{b 93}+\omega_{b 94}+\omega_{b 95}+\omega_{b 96}+\omega_{f 97}}{k_{b 91}\left[N_{2}\right]+k_{f 93}[M]+\left(k_{b 84}+k_{b 87}+k_{f 94}\right)[H]+k_{f 95}[O H]+k_{b 97}[N O]+k_{f 96}\left[N H_{2}\right]}}
\end{gathered}
$$

where $\omega_{\mathrm{fi}}$ is the forward reaction rate of reaction number i. Since the nitrogen chemistry is not expected to significantly alter combustion, none of the reactions describing the nitrogen chemistry appears in steady-state equations for non-nitrogen containing species.

The four reactions of the reduced mechanism that describe combustion are taken from Glarborg et al. (1992); our derivation is identical to theirs, but we will repeat the reactions and rates here for completeness and to avoid propagating errors. Glarborg et al. developed the rates following the well-established procedure of Peters and coworkers, adding net production rates of steadystate species to eliminate elementary rates from the reduced rate. Glarborg et al. also truncated several of the global rates, neglecting the less significant elementary reactions in the summations. The reduced reactions are:

$$
\begin{gathered}
\text { I. } \mathrm{CH}_{4}+2 \mathrm{H}+\mathrm{H}_{2} \mathrm{O} \rightleftharpoons \mathrm{CO}+4 \mathrm{H}_{2} \\
\text { II. } \mathrm{CO}+\mathrm{H}_{2} \mathrm{O} \rightleftharpoons \mathrm{CO}_{2}+\mathrm{H}_{2} \\
\text { III. } 2 \mathrm{H}+\mathrm{M \rightleftharpoons H} \rightleftharpoons \mathrm{H} \\
\text { IV. } 3 \mathrm{H}_{2}+\mathrm{O}_{2} \rightleftharpoons 2 \mathrm{H}_{2} \mathrm{O}+2 \mathrm{H}
\end{gathered}
$$

The rates for these equations are: 


$$
\begin{aligned}
\omega_{I} & =\omega_{10}+\omega_{11}+\omega_{12}-\omega_{13}-\omega_{22} \\
\omega_{I I} & =\omega_{9} \\
\omega_{I I I} & =\omega_{5}+\omega_{6}+\omega_{13}+\omega_{19}-\omega_{20}-\omega_{21}+\omega_{22}+\omega_{24}+\omega_{28}+\omega_{29}+\omega_{30} \\
\omega_{I V} & =\omega_{1}+\omega_{7}+\omega_{20}+\omega_{21}+\omega_{37}
\end{aligned}
$$

where $\omega_{i}$ represents the difference of the forward and reverse rates for reaction $i$.

Normally, in the course of developing a reduced mechanism, we would now formulate global rates for the nitrogen chemistry. For instance we could express $\mathrm{NO}$ formation as $\mathrm{N}_{2}+\mathrm{O}_{2}=2 \mathrm{NO}$. Of course this expression has no physical meaning since $\mathrm{N}_{2}$ does not react directly with $\mathrm{O}_{2}$. The main purpose of this equation is to handle bookeeping for production and destruction of the species in the different reactions. But, because NO only appears in a single global reaction, and $\mathrm{N}_{2}$ and $\mathrm{O}_{2}$ concentrations are nearly unaffected by the rate of $\mathrm{NO}$ formation, global rates for the nitrogen chemistry are unnecessary. Instead, we can express the net rates of production of the nitrogenated species directly. Again adding rates of steady-state species to eliminate elementary reactions, we have arrived at the following reduced expressions for the net rates of production of the nitrogenated species:

$$
\begin{aligned}
& \omega_{N O}=-2 \omega_{54}-2 \omega_{57}+\omega_{61}+\omega_{66}+\omega_{67}-\omega_{68}+\omega_{69}+\omega_{70}-\omega_{71}-\omega_{72}-\omega_{73} \\
& -\omega_{74}-\omega_{77}+\omega_{81}+\omega_{82}+\omega_{83}+\omega_{84}-\omega_{85}-\omega_{92} \\
& \omega_{H C N}=-\omega_{61}-\omega_{66}-\omega_{67}-\omega_{68}+\omega_{69}+\omega_{70}+\omega_{71}+\omega_{72}+\omega_{73}+\omega_{74}+\omega_{77} \\
& \omega_{N_{3}}=-\omega_{81}-\omega_{82}-\omega_{83}-\omega_{84}-\omega_{85}-\omega_{89}-\omega_{90}-\omega_{91}
\end{aligned}
$$

\section{Reduced Mechanism Validation}

The stirred reactor was modeled using the PSR FORTRAN program written at Sandia, with CHEMKIN II and the Sandia database for transport and thermochemistry. Minor modifications were made to allow modeling with reduced mechanisms.

Figures 1,2 and 3 show the performance of the mechanism over a range of reactor residence 
times for a constant reactor temperature of $1700 \mathrm{~K}$. The smallest time, $\tau=10^{-4} \mathrm{~s}$, represents the approximate residence time in a flame front, while the largest time, $\tau=10^{-1} \mathrm{~s}$, is about the residence time in a turbine combustor. Three cases were considered: (1) methane-air combustion with no nitrogenated species in the reactants (Fig. 1), (2) methane-air combustion with 1000 ppmV NO in the reactants (Fig. 2), and (3) methane-air combustion with $1000 \mathrm{ppmV} \mathrm{NH}_{3}$ in the reactants (Fig. 3). The first two cases are identical to those considered by Glarborg et al. (1992) and are only reproduced here to show that no accuracy has been lost in expanding the mechanism. The third case is meant to represent syn gas combustion with a typical $\mathrm{NH}_{3}$ level from a gasifier.

The agreement is generally very good for all cases and mechanisms considered. The excellent agreement observed between the reduced and skeletal mechanisms for all conditions suggests that the steady-state and partial-equilibrium assumptions applied to create the reduced mechanism are sound. The largest discrepancies observed are those for the detailed and skeletal mechanisms at fuel-rich conditions where $\mathrm{C}_{2}$ chemistry and reactions between nitrogenated species become more important. A small part of the discrepancy is caused by small changes in the elementary rate coefficients which were previously introduced by Glarborg. As Fig. 3 suggests, no major $\mathrm{NH}_{3}$ pathway appears to have been neglected. Nor do any of the added reactions affect the agreement observed by Glarborg et al. (Figs. 1 and 2).

Figures 4, 5, and 6 show tests of the same three cases for varying reactor temperature $(1300 \mathrm{~K}$ to $2000 \mathrm{~K}$ ) at a fixed residence time of $10^{-2} \mathrm{~s}$. The agreement is generally the same as that observed in Figs. 1, 2, and 3, with the largest discrepancy observed for fuel-rich, low-temperature combustion. Again, most of the discrepancy observed arises from the neglect of $\mathrm{C}_{2}$ chemistry in the skeletal mechanism.

\section{Summary}

A reduced mechanism has been created to model syn-gas combustion with $\mathrm{NH}_{3}$ present in the reactants. The mechanism contains rates for 10 non-steady-state species $\left(\mathrm{CH}_{4}, \mathrm{H}_{2}, \mathrm{O}_{2}, \mathrm{CO}, \mathrm{H}_{2} \mathrm{O}\right.$, $\mathrm{H}, \mathrm{CO}_{2}, \mathrm{~N}_{2}, \mathrm{NO}, \mathrm{HCN}$, and $\mathrm{NH}_{3}$ ), as well as a partial equilibrium relation for one species $(\mathrm{OH})$, and steady-state relations for 18 species $\left(\mathrm{O}, \mathrm{CH}_{3},{ }^{3} \mathrm{CH}_{2}, \mathrm{CH}_{2}, \mathrm{CH}_{2} \mathrm{OH}, \mathrm{CH}_{2} \mathrm{O}, \mathrm{CH}, \mathrm{HCO}, \mathrm{C}, \mathrm{HO}_{2}\right.$, $\mathrm{CN}, \mathrm{NCO}, \mathrm{NH}, \mathrm{N}, \mathrm{N}_{2} \mathrm{O}, \mathrm{NH}_{2}, \mathrm{NNH}, \mathrm{HNO}$ ). The reduced mechanism is based on a skeletal mechanism containing 96 reactions which were chosen to model hydrocarbon oxidation and nitrogen chemistry with an emphasis on correct prediction of radical concentrations.

All performance calculations were executed for a perfectly stirred reactor. Three cases were considered: (1) methane-air combustion with no nitrogenated species in the reactants, (2) methane-air combustion with $1000 \mathrm{ppmV}$ NO in the reactants, and (3) methane-air combustion

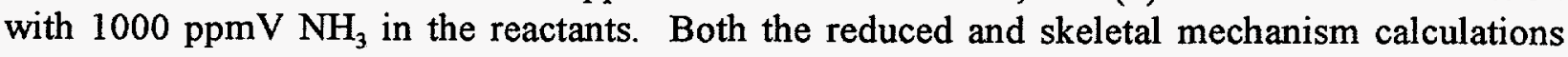
agree very well with calculations using a detailed mechanism for a range of reactor residence 
times $\left(10^{-4}\right.$ to $\left.10^{-1} \mathrm{~s}, \mathrm{~T}=1700 \mathrm{~K}\right)$ and temperatures $\left(1300\right.$ to $\left.2000 \mathrm{~K}, \tau=10^{-2} \mathrm{~s}\right)$. The largest discrepancies were observed for fuel-rich combustion at low temperatures. For these conditions, the skeletal mechanism disagrees with the detailed mechanism, suggesting that $\mathrm{C}_{2}$ reactions important for these conditions have been neglected in the skeletal mechanism.

Future work will test the performance of the reduced and skeletal mechanisms in models of laminar, counterflow flames. If the mechanisms succeed in modeling the chemistry in both the PSR and these flames, then we expect them to succeed in modeling turbulent flames, which are composed primarily of distributed reaction zones (similar to combustion in the PSR) and flamelets (similar to counterflow flames).

\section{Acknowledgements}

This work was performed while one of the authors (D. M.) held a National Research CouncilMorgantown Energy Technology Center Research Associateship.

\section{References}

Barlow, R. S. and Carter, C. D. (1994): Combust. Flame, 97:261-280.

Chung, S. H. and Lee, S. R. (1993): in Reduced Kinetic Mechanisms for Applications in Combustion Systems (Peters and Rogg, Eds.), Lecture Notes in Physics m15, Springer-Verlag, p. 308.

Dean, A. J., Davidson, D. F., Hanson, R. K., and Bowman, C. T. (1990): Twenty-third Symposium (International) on Combustion, The Combustion Institute, p. 259.

Drake, M. C., Pitz, R. W., Correa, S. M., and Lapp, M. (1984): Twentieth Symposium (International) on Combustion, The Combustion Institute, p. 1983.

Glarborg, P., Kee, R. J., Grcar, M. D., and Miller, J. A. (1986): PSR: A Fortran Program for Modeling Well-Stirred Reactors, Sandia Report SAND86-8209, Sandia National Laboratories, Livermore, CA.

Glarborg, P., Lilleheie, N. I., Byggstoyl, S., Magnussen, B. F., Kilpinen, P., and Hupa, M. (1992): Twenty-fourth Symposium (International) on Combustion, The Combustion Institute, p. 889.

Kee, R. J., Rupley, F. M., and Miller, J. A. (1989): CHEMKIN-II: A Fortran Chemical Kinetics Package for the Analysis of Gas-Phase Chemical Kinetics, Sandia Report SAND898009, Sandia National Laboratories, Livermore, CA. 
Lindstedt, R. P. and Selim, M. A. (1994): Combust. Sci. and Tech., 99:277-298.

Miller, J. A. and Bowman, C. T. (1989): Prog. Energy Combust. Sci., 15:287-338.

Peters, N. (1991): in Reduced Kinetic Mechanisms and Asymptotic Approximations for Methane-Air Flames (Smooke, Ed.), Lecture Notes in Physics 384, Springer-Verlag, p. 48.

Table I: Skeletal mechanism for methane/air combustion with $\mathrm{NH}_{3}$ present in the reactants. Units are cal, moles, cm, and s. Rates for the first 77 reactions are taken from Glarborg et al. (1992), while the rates for the last 20 reactions are from Miller and Bowman.

\begin{tabular}{|c|c|c|c|c|}
\hline & & A & $\beta$ & $\mathrm{E}$ \\
\hline 1. & $\mathrm{H}+\mathrm{O}_{2} \Leftrightarrow \mathrm{O}+\mathrm{OH}$ & $3.5 \mathrm{E}+16$ & -0.70 & 17070 \\
\hline 2. & $\mathrm{O}+\mathrm{H}_{2} \Leftrightarrow \mathrm{OH}+\mathrm{H}$ & $5.0 \mathrm{E}+04$ & 2.67 & 6290 \\
\hline 3. & $\mathrm{OH}+\mathrm{H}_{2} \Leftrightarrow \mathrm{H}_{2} \mathrm{O}+\mathrm{H}$ & $5.9 \mathrm{E}+08$ & 1.37 & 3520 \\
\hline 4. & $\mathrm{OH}+\mathrm{OH} \Leftrightarrow \mathrm{H}_{2} \mathrm{O}+\mathrm{O}$ & $2.1 \mathrm{E}+08$ & 1.40 & -400 \\
\hline 5. & $\mathrm{H}+\mathrm{OH}+\mathrm{M} \Rightarrow \mathrm{H}_{2} \mathrm{O}+\mathrm{M}$ & $7.5 \mathrm{E}+21$ & -2.00 & 0 \\
\hline \multicolumn{5}{|c|}{ Third Body Efficiencies: $\mathrm{N}_{2} / 2 / \quad \mathrm{CO}_{2} / 4 / \quad \mathrm{H}_{2} \mathrm{O} / 15 /$} \\
\hline 6. & $\mathrm{H}+\mathrm{O}_{2}+\mathrm{M} \Rightarrow \mathrm{HO}_{2}+\mathrm{M}$ & $7.0 \mathrm{E}+17$ & -0.80 & 0 \\
\hline & Third Body Efficiencies: $\mathrm{H}_{2} \mathrm{O} / 18.6 /$ & $\mathrm{CO}_{2} / 4.2 /$ & $\mathrm{H}_{2} / 3.33 /$ & $/ 2.11 /$ \\
\hline 7. & $\mathrm{HO}_{2}+\mathrm{H} \Rightarrow \mathrm{OH}+\mathrm{OH}$ & $2.5 \mathrm{E}+14$ & 0.00 & 1900 \\
\hline 8. & $\mathrm{HO}_{2}+\mathrm{OH} \Rightarrow \mathrm{H}_{2} \mathrm{O}+\mathrm{O}_{2}$ & $3.9 \mathrm{E}+13$ & 0.00 & -50 \\
\hline 9. & $\mathrm{CO}+\mathrm{OH} \Leftrightarrow \mathrm{CO}_{2}+\mathrm{H}$ & $1.5 \mathrm{E}+07$ & 1.30 & -760 \\
\hline 10. & $\mathrm{CH}_{4}+\mathrm{H} \Leftrightarrow \mathrm{CH}_{3}+\mathrm{H}_{2}$ & $2.2 \mathrm{E}+04$ & 3.00 & 8750 \\
\hline 11. & $\mathrm{CH}_{4}+\mathrm{O} \Rightarrow \mathrm{CH}_{3}+\mathrm{OH}$ & $3.7 \mathrm{E}+07$ & 1.91 & 7690 \\
\hline 12. & $\mathrm{CH}_{4}+\mathrm{OH} \Leftrightarrow \mathrm{CH}_{3}+\mathrm{H}_{2} \mathrm{O}$ & $1.3 \mathrm{E}+06$ & 2.18 & 2530 \\
\hline 13. & $\mathrm{CH}_{3}+\mathrm{H} \Rightarrow \mathrm{CH}_{4}$ & $2.6 \mathrm{E}+28$ & -5.11 & -2627 \\
\hline 14. & $\mathrm{CH}_{3}+\mathrm{H} \Leftrightarrow{ }^{3} \mathrm{CH}_{2}+\mathrm{H}_{2}$ & $9.0 \mathrm{E}+13$ & 0.00 & 15100 \\
\hline 15. & ${ }^{1} \mathrm{CH}_{2}+\mathrm{H}_{2} \Leftrightarrow \mathrm{CH}_{3}+\mathrm{H}$ & $5.8 \mathrm{E}+13$ & 0.00 & 0 \\
\hline 16. & $\mathrm{CH}_{3}+\mathrm{O} \Rightarrow \mathrm{CH}_{2} \mathrm{O}+\mathrm{H}$ & $8.4 \mathrm{E}+13$ & 0.00 & 0 \\
\hline
\end{tabular}




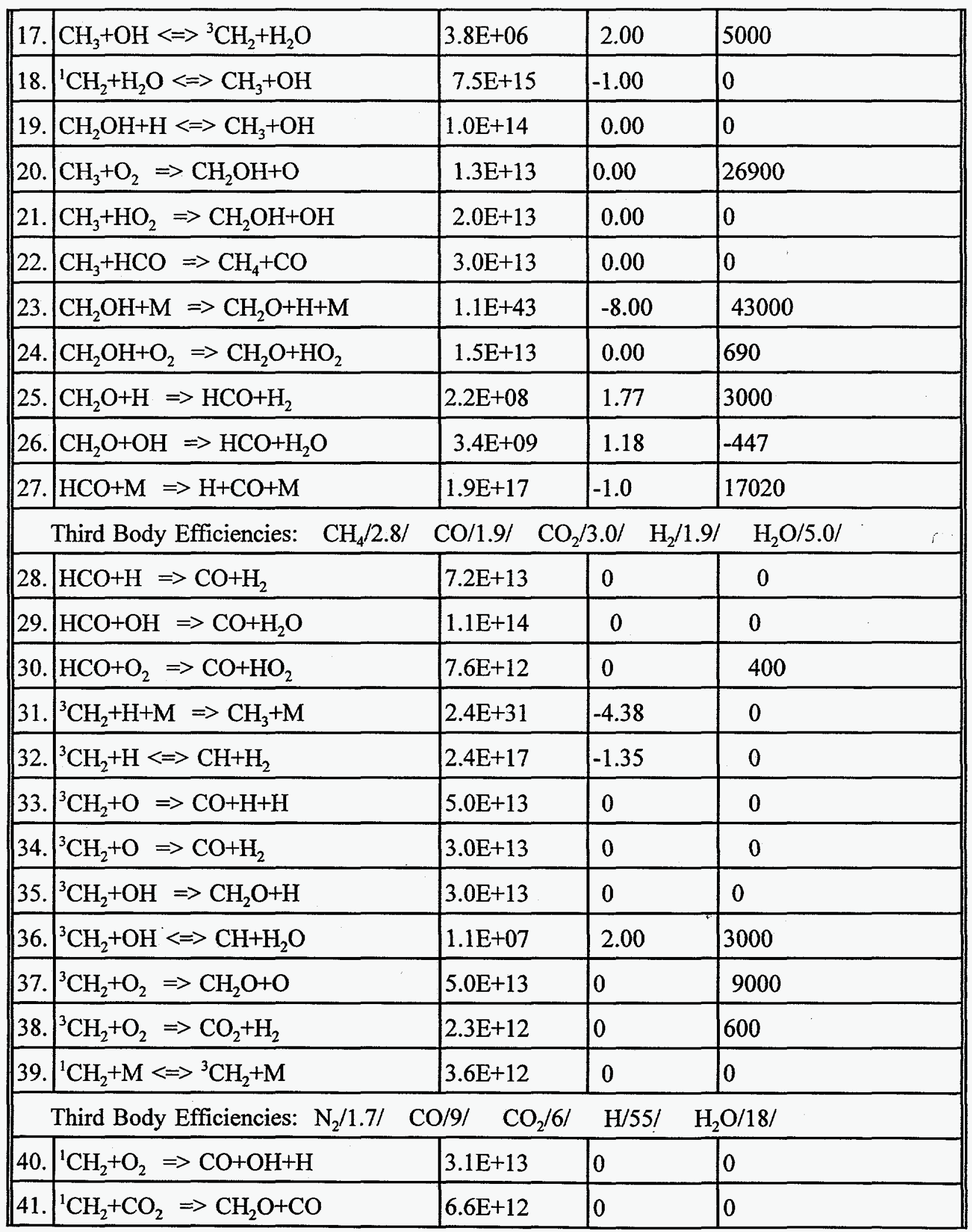




\begin{tabular}{|c|c|c|c|c|}
\hline 42. & $\mathrm{CH}+\mathrm{H} \Leftrightarrow \mathrm{C}+\mathrm{H}_{2}$ & $1.1 \mathrm{E}+14$ & 0 & 0 \\
\hline 43. & $\mathrm{CH}+\mathrm{O} \Rightarrow \mathrm{CO}+\mathrm{H}$ & $6.0 \mathrm{E}+13$ & 0 & 0 \\
\hline 44. & $\mathrm{CH}+\mathrm{OH} \Rightarrow \mathrm{HCO}+\mathrm{H}$ & $3.0 \mathrm{E}+13$ & 0 & 0 \\
\hline 45. & $\mathrm{CH}+\mathrm{OH} \Leftrightarrow \mathrm{C}+\mathrm{H}_{2} \mathrm{O}$ & $4.0 \mathrm{E}+07$ & 2.00 & 3000 \\
\hline 46. & $\mathrm{CH}+\mathrm{O}_{2} \Rightarrow \mathrm{HCO}+\mathrm{O}$ & $3.3 \mathrm{E}+13$ & 0 & 0 \\
\hline 47. & $\mathrm{CH}+\mathrm{H}_{2} \mathrm{O} \Rightarrow \mathrm{CH}_{2} \mathrm{O}+\mathrm{H}$ & $1.3 \mathrm{E}+15$ & -0.75 & 0 \\
\hline 48. & $\mathrm{CH}+\mathrm{CO}_{2} \Rightarrow \mathrm{HCO}+\mathrm{CO}$ & $3.4 \mathrm{E}+12$ & 0 & 686 \\
\hline 49. & $\mathrm{C}+\mathrm{OH} \Rightarrow \mathrm{CO}+\mathrm{H}$ & $5.0 \mathrm{E}+13$ & 0 & 0 \\
\hline 50. & $\mathrm{C}+\mathrm{O}_{2} \Rightarrow \mathrm{CO}+\mathrm{O}$ & $6.0 \mathrm{E}+13$ & 0 & 650 \\
\hline 51. & $\mathrm{NH}+\mathrm{H} \Leftrightarrow \mathrm{N}+\mathrm{H}_{2}$ & $3.0 \mathrm{E}+13$ & 0 & 0 \\
\hline 52. & $\mathrm{NH}+\mathrm{O} \Leftrightarrow \mathrm{NO}+\mathrm{H}$ & $5.5 \mathrm{E}+13$ & 0 & 0 \\
\hline 53. & $\mathrm{NH}+\mathrm{O} \Leftrightarrow \mathrm{N}+\mathrm{OH}$ & $7.0 \mathrm{E}+11$ & 0.50 & 0 \\
\hline 54. $]$ & $\mathrm{NH}+\mathrm{NO} \Leftrightarrow \mathrm{N}_{2} \mathrm{O}+\mathrm{H}$ & $1.2 \mathrm{E}+14$ & -0.30 & 0 \\
\hline 55. & $\mathrm{~N}+\mathrm{OH} \Leftrightarrow \mathrm{NO}+\mathrm{H}$ & $3.8 \mathrm{E} 13$ & 0 & 0 \\
\hline 56. & $\mathrm{~N}+\mathrm{O}_{2} \Leftrightarrow \mathrm{NO}+\mathrm{O}$ & $6.4 \mathrm{E}+09$ & 1.00 & 6280 \\
\hline 57. & $\mathrm{~N}+\mathrm{NO} \Leftrightarrow \mathrm{N}_{2}+\mathrm{O}$ & $3.3 \mathrm{E}+12$ & 0.30 & 0 \\
\hline 58. & $\mathrm{N}_{2} \mathrm{O}+\mathrm{M} \Leftrightarrow \mathrm{N}_{2}+\mathrm{O}+\mathrm{M}$ & $7.0 \mathrm{E}+14$ & 0 & 56350 \\
\hline \multicolumn{2}{|r|}{ Third Body Efficiencies: $\mathrm{H}_{2} \mathrm{O} / 5 /$} & \multicolumn{2}{|c|}{$\mathrm{N}_{2} / 1.5 /$} & \\
\hline 59. & $\mathrm{~N}_{2} \mathrm{O}+\mathrm{H} \Rightarrow \mathrm{N}_{2}+\mathrm{OH}$ & $7.6 \mathrm{E}+13$ & 0 & 15200 \\
\hline 60. & $\mathrm{HCN}+\mathrm{O} \Rightarrow \mathrm{NCO}+\mathrm{H}$ & $1.4 \mathrm{E}+04$ & 2.64 & 4980 \\
\hline 61. & $\mathrm{HCN}+\mathrm{O} \Rightarrow \mathrm{NH}+\mathrm{CO}$ & $3.5 \mathrm{E}+03$ & 2.64 & 4980 \\
\hline 62. & $\mathrm{HCN}+\mathrm{OH} \Leftrightarrow \mathrm{CN}+\mathrm{H}_{2} \mathrm{O}$ & $1.5 \mathrm{E}+15$ & -0.68 & 12380 \\
\hline 63. & $\mathrm{HCN}+\mathrm{OH}=\mathrm{NCO}+\mathrm{H}_{2}$ & $5.5 \mathrm{E}+03$ & 2.67 & 10800 \\
\hline 64. & $\mathrm{CN}+\mathrm{OH} \Rightarrow \mathrm{NCO}+\mathrm{H}$ & $6.0 \mathrm{E}+13$ & 0 & 0 \\
\hline 65. & $\mathrm{CN}+\mathrm{O}_{2} \Rightarrow \mathrm{NCO}+\mathrm{O}$ & $1.0 \mathrm{E}+13$ & 0 & 0 \\
\hline 66. & $\mathrm{NCO}+\mathrm{H} \Rightarrow \mathrm{CO}+\mathrm{NH}$ & $5.0 \mathrm{E}+13$ & 0 & 0 \\
\hline 67. & $\mathrm{NCO}+\mathrm{OH} \Rightarrow \mathrm{NO}+\mathrm{CO}+\mathrm{H}$ & $1.0 \mathrm{E}+13$ & 0 & 0 \\
\hline
\end{tabular}




\begin{tabular}{|c|c|c|c|c|}
\hline 68. & $\mathrm{NCO}+\mathrm{NO} \Rightarrow \mathrm{N}_{2} \mathrm{O}+\mathrm{CO}$ & $3.0 \mathrm{E}+17$ & -1.53 & 260 \\
\hline 69. & $\mathrm{CH}+\mathrm{N}_{2} \Rightarrow \mathrm{HCN}+\mathrm{N}$ & $4.4 \mathrm{E}+12$ & 0 & 22000 \\
\hline 70. & $\mathrm{C}+\mathrm{N}_{2} \Rightarrow \mathrm{CN}+\mathrm{N}$ & $6.3 \mathrm{E}+13$ & 0 & 46000 \\
\hline 71. & ${ }^{3} \mathrm{CH}_{2}+\mathrm{NO} \Rightarrow \mathrm{HCN}+\mathrm{OH}$ & $2.3 E+12$ & 0 & -1100 \\
\hline 72. & ${ }^{1} \mathrm{CH}_{2}+\mathrm{NO} \Rightarrow \mathrm{HCN}+\mathrm{OH}$ & $1.0 \mathrm{E}+14$ & 0 & 0 \\
\hline 73. & $\mathrm{CH}+\mathrm{NO} \Rightarrow \mathrm{HCN}+\mathrm{O}$ & $1.1 \mathrm{E}+14$ & 0 & 0 \\
\hline 74. & $\mathrm{C}+\mathrm{NO} \Rightarrow \mathrm{CN}+\mathrm{O}$ & $1.9 \mathrm{E}+13$ & 0 & 0 \\
\hline 75. & $\mathrm{C}+\mathrm{NO} \Rightarrow \mathrm{CO}+\mathrm{N}$ & $2.9 \mathrm{E} 13$ & 0 & 0 \\
\hline 76. & $\mathrm{~N}+\mathrm{CO}_{2} \Rightarrow \mathrm{NO}+\mathrm{CO}$ & $1.3 \mathrm{E}+12$ & 0 & 4950 \\
\hline 77. & $\mathrm{~N}+\mathrm{CH}_{3} \Rightarrow \mathrm{HCN}+2 \mathrm{H}$ & $7.1 \mathrm{E}+13$ & 0 & 0 \\
\hline 78. & $\mathrm{NH}_{3}+\mathrm{H} \Leftrightarrow \Rightarrow \mathrm{NH}_{2}+\mathrm{H}_{2}$ & $6.36 \mathrm{E}+05$ & 2.39 & 10171 \\
\hline 79. & $\mathrm{NH}_{3}+\mathrm{OH}=\mathrm{NH}_{2}+\mathrm{H}_{2} \mathrm{O}$ & $2.04 \mathrm{E}+06$ & 2.04 & 566 \\
\hline 80. & $\mathrm{NH}_{3}+\mathrm{O} \Leftrightarrow>\mathrm{NH}_{2}+\mathrm{OH}$ & $2.10 \mathrm{E}+13$ & 0 & 9000 \\
\hline 81. & $\mathrm{NH}_{2}+\mathrm{H} \Leftrightarrow \mathrm{NH}+\mathrm{H}_{2}$ & $6.92 \mathrm{E}+13$ & 0 & 3650 \\
\hline 82. & $\mathrm{NH}_{2}+\mathrm{OH} \Leftrightarrow \Rightarrow \mathrm{NH}+\mathrm{H}_{2} \mathrm{O}$ & $4.00 \mathrm{E}+06$ & 2 & 1000 \\
\hline 83. & $\mathrm{NH}_{2}+\mathrm{O} \Leftrightarrow \mathrm{NH}+\mathrm{OH}$ & $6.75 \mathrm{E}+12$ & 0 & 0 \\
\hline 84. & $\mathrm{NH}_{2}+\mathrm{O} \Leftrightarrow>\mathrm{HNO}+\mathrm{H}$ & $6.63 E+14$ & -0.50 & 0 \\
\hline 85. & $\mathrm{NH}_{2}+\mathrm{NO} \Leftrightarrow \mathrm{N}_{2}+\mathrm{H}_{2} \mathrm{O}$ & $6.20 \mathrm{E}+15$ & -1.25 & 0 \\
\hline 86. & $\mathrm{NH}+\mathrm{OH} \Leftrightarrow \mathrm{N}+\mathrm{H}_{2} \mathrm{O}$ & $5.00 \mathrm{E}+11$ & 0.50 & 2000.000 \\
\hline 87. & $\mathrm{NH}+\mathrm{OH}<\Rightarrow \mathrm{HNO}+\mathrm{H}$ & $2.00 \mathrm{E}+13$ & 0 & 0 \\
\hline 88. & $\mathrm{NH}+\mathrm{O}_{2} \Leftrightarrow \mathrm{NO}+\mathrm{OH}$ & $7.60 \mathrm{E}+10$ & 0 & 1530 \\
\hline 89. & $\mathrm{NNH}+\mathrm{OH} \Leftrightarrow \Rightarrow \mathrm{N}_{2}+\mathrm{H}_{2} \mathrm{O}$ & $5.00 \mathrm{E}+13$ & 0 & 0 \\
\hline 90. & $\mathrm{NNH}+\mathrm{NH}_{2} \Leftrightarrow \Rightarrow \mathrm{N}_{2}+\mathrm{NH}_{3}$ & $5.00 \mathrm{E}+13$ & 0 & 0 \\
\hline 91. & $\mathrm{NNH}+\mathrm{NO}<=>\mathrm{N}_{2}+\mathrm{HNO}$ & $5.00 \mathrm{E}+13$ & 0.000 & 0.000 \\
\hline 92. & $\mathrm{NH}_{2}+\mathrm{NO} \Leftrightarrow \mathrm{NNH}+\mathrm{OH}$ & $6.40 \mathrm{E}+15$ & -1.250 & 0.000 \\
\hline 93. & $\mathrm{HNO}+\mathrm{M}<=>\mathrm{H}+\mathrm{NO}+\mathrm{M}$ & $1.50 \mathrm{E}+16$ & 0 & 48680 \\
\hline & Third Body Efficiencies: & $\mathrm{O}_{2} / 2 / \quad \mathrm{N}_{2} / 2 /$ & $\mathrm{H}_{2} / 2 /$ & \\
\hline
\end{tabular}




\begin{tabular}{|r|l|l|l|l||}
\hline 94. & $\mathrm{HNO}+\mathrm{H} \Leftrightarrow>\mathrm{H}_{2}+\mathrm{NO}$ & $5.00 \mathrm{E}+12$ & 0 & 0 \\
\hline 95. & $\mathrm{HNO}+\mathrm{OH} \Leftrightarrow>\mathrm{NO}+\mathrm{H}_{2} \mathrm{O}$ & $3.60 \mathrm{E}+13$ & 0 & 0 \\
\hline 96. & $\mathrm{HNO}+\mathrm{NH}_{2} \Leftrightarrow>\mathrm{NH}_{3}+\mathrm{NO}$ & $2.00 \mathrm{E}+13$ & 0.000 & 1000.000 \\
\hline 97. & $\mathrm{NH}+\mathrm{O}_{2} \Leftrightarrow>\mathrm{HNO}+\mathrm{O}$ & $1.00 \mathrm{E}+13$ & 0.000 & 12000.000 \\
\hline
\end{tabular}


D. Marlow and T. S. Norton

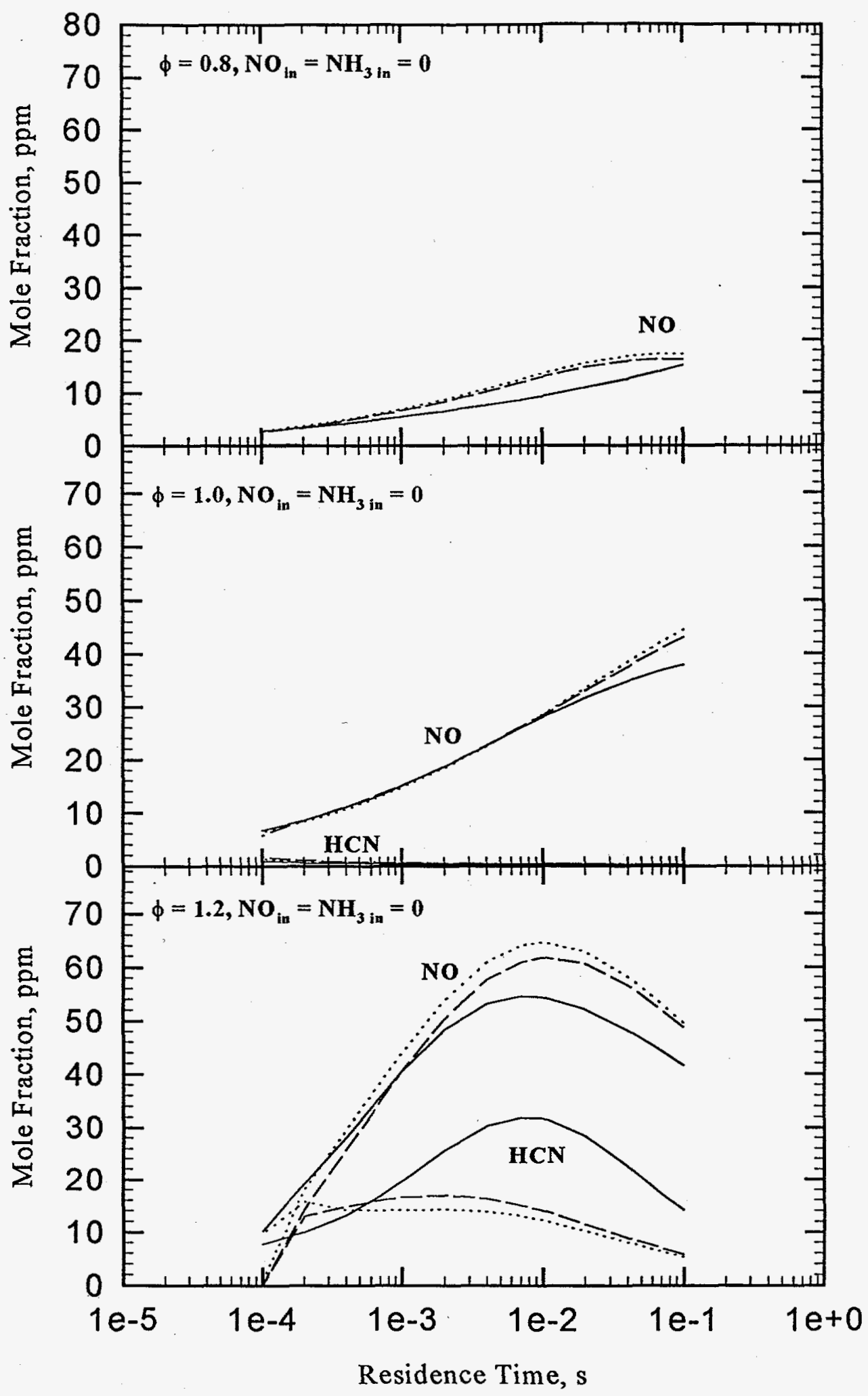

Figure 1: Methane-air combustion in a perfectly-stirred reactor at a constant temperature of $1700 \mathrm{~K}$ : solid lines, detailed mechanism of Miller and Bowman; dashed lines, skeletal mechanism; dotted lines, reduced mechanism. 
D. Marlow and T. S. Norton

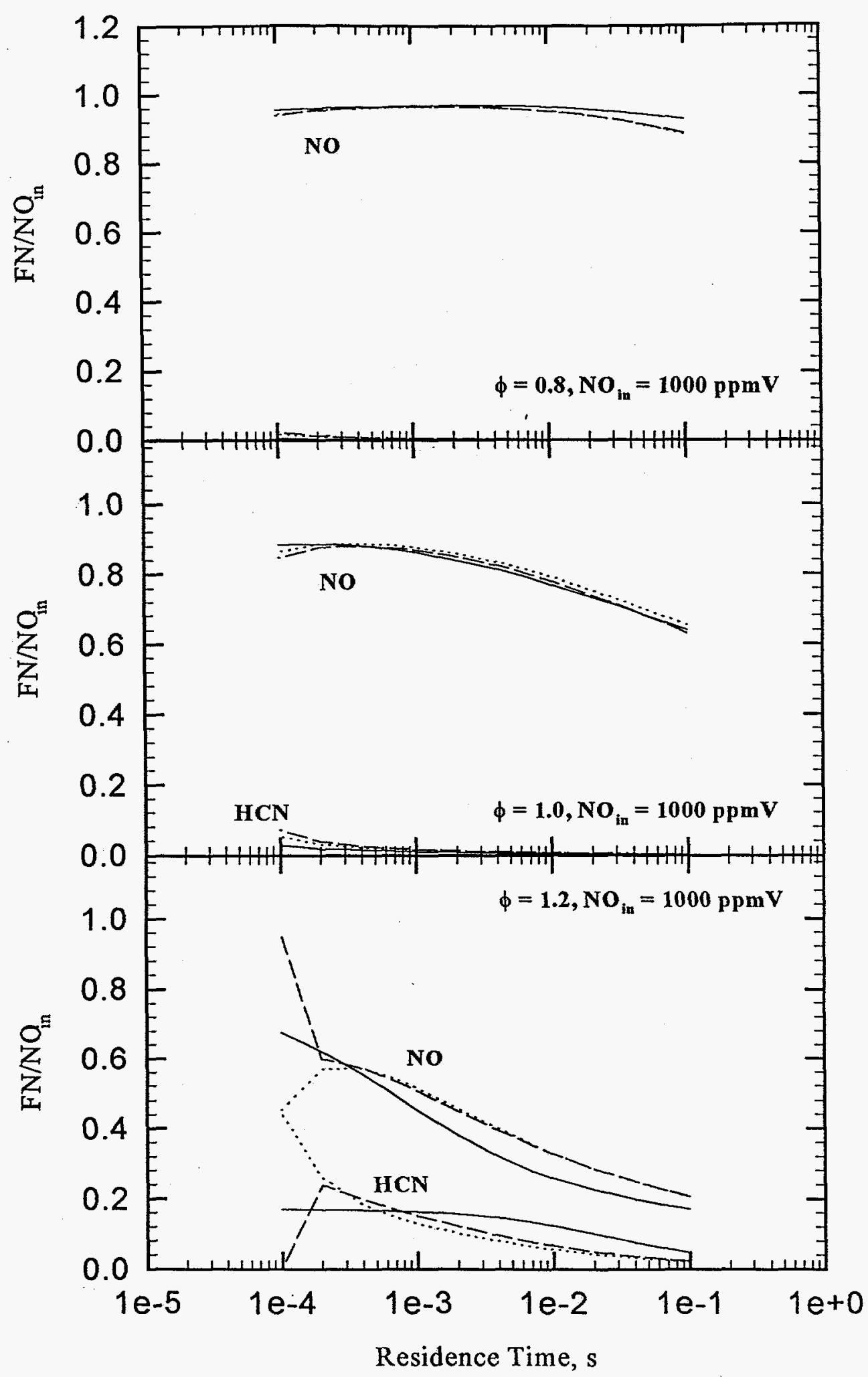

Figure 2: Methane-air combustion in a perfectly-stirred reactor at a constant temperature of $1700 \mathrm{~K}$. Line symbols are the same as above. Molar ratios are plotted, where FN indicates the corresponding species. 
D. Marlow and T. S. Norton

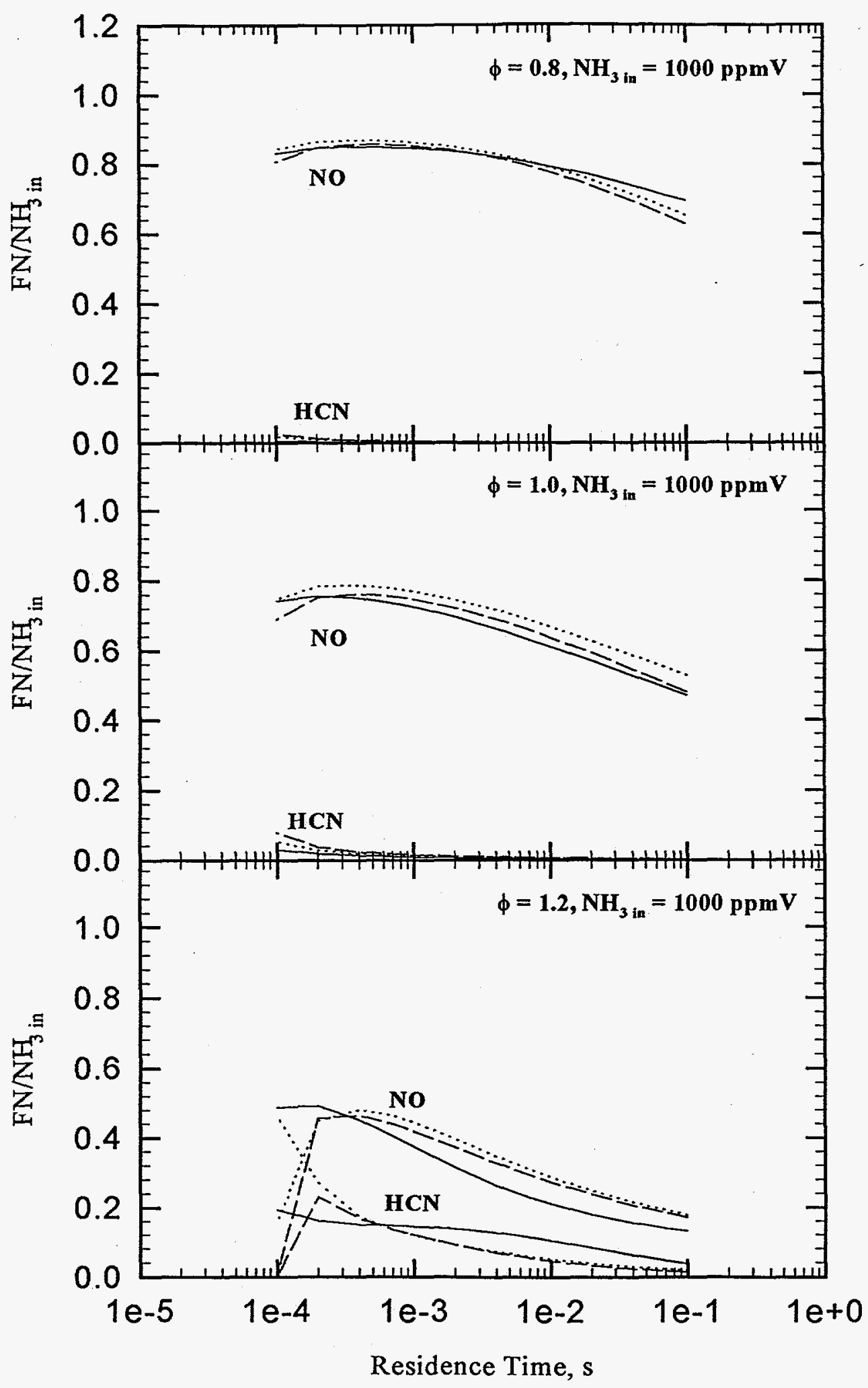

Figure 3: Methane-air combustion in a perfectly-stirred reactor at a constant temperature of $1700 \mathrm{~K}$. Line symbols are the same as above. Molar ratios are plotted, where FN indicates the corresponding species. 


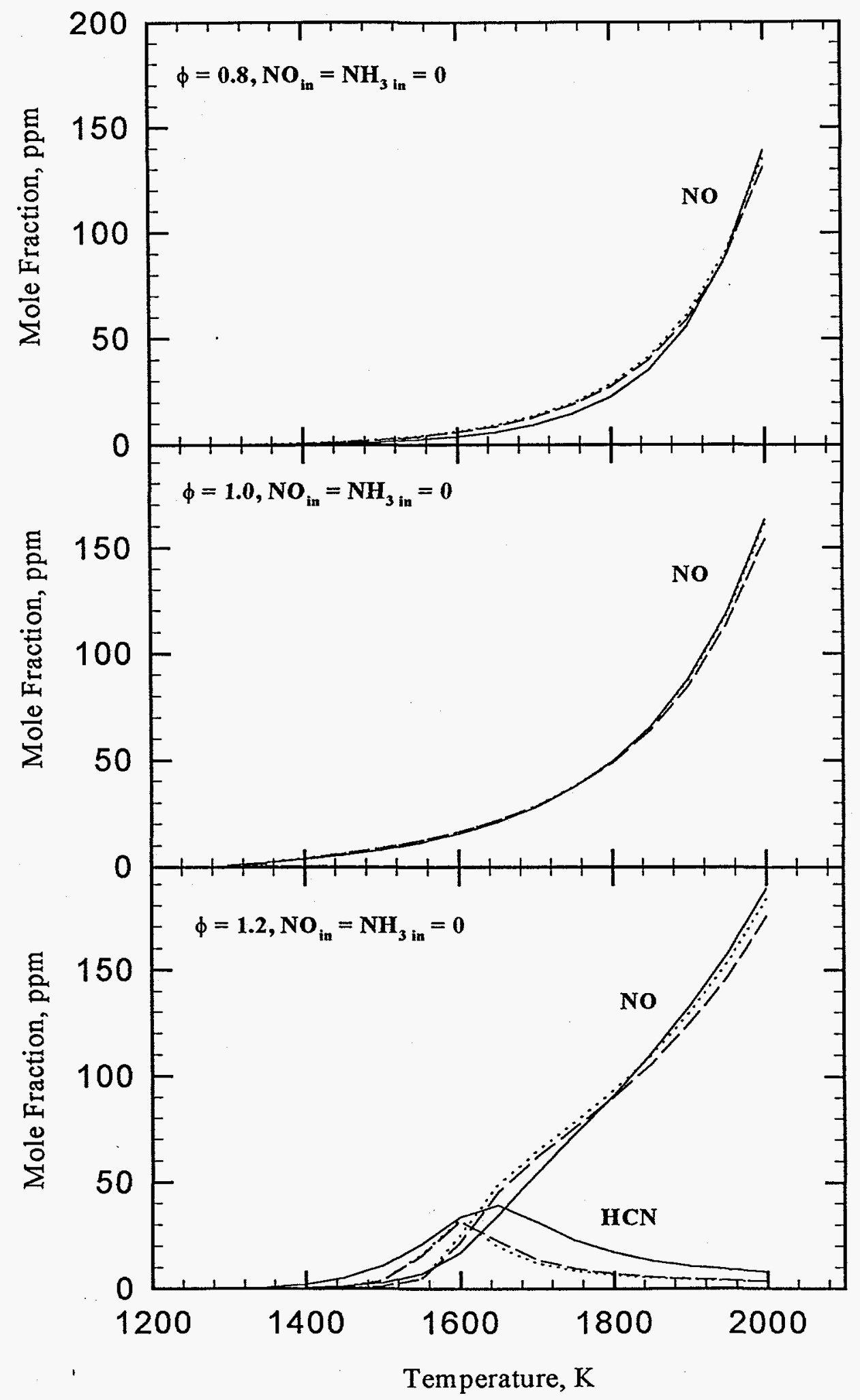

Figure 4: Methane-air combustion at a constant residence time of $10^{-2} \mathrm{~s}$ : solid lines, detailed mechanism of Miller and Bowman; dashed lines, skeletal mechanism; dotted lines, reduced mechanism. 


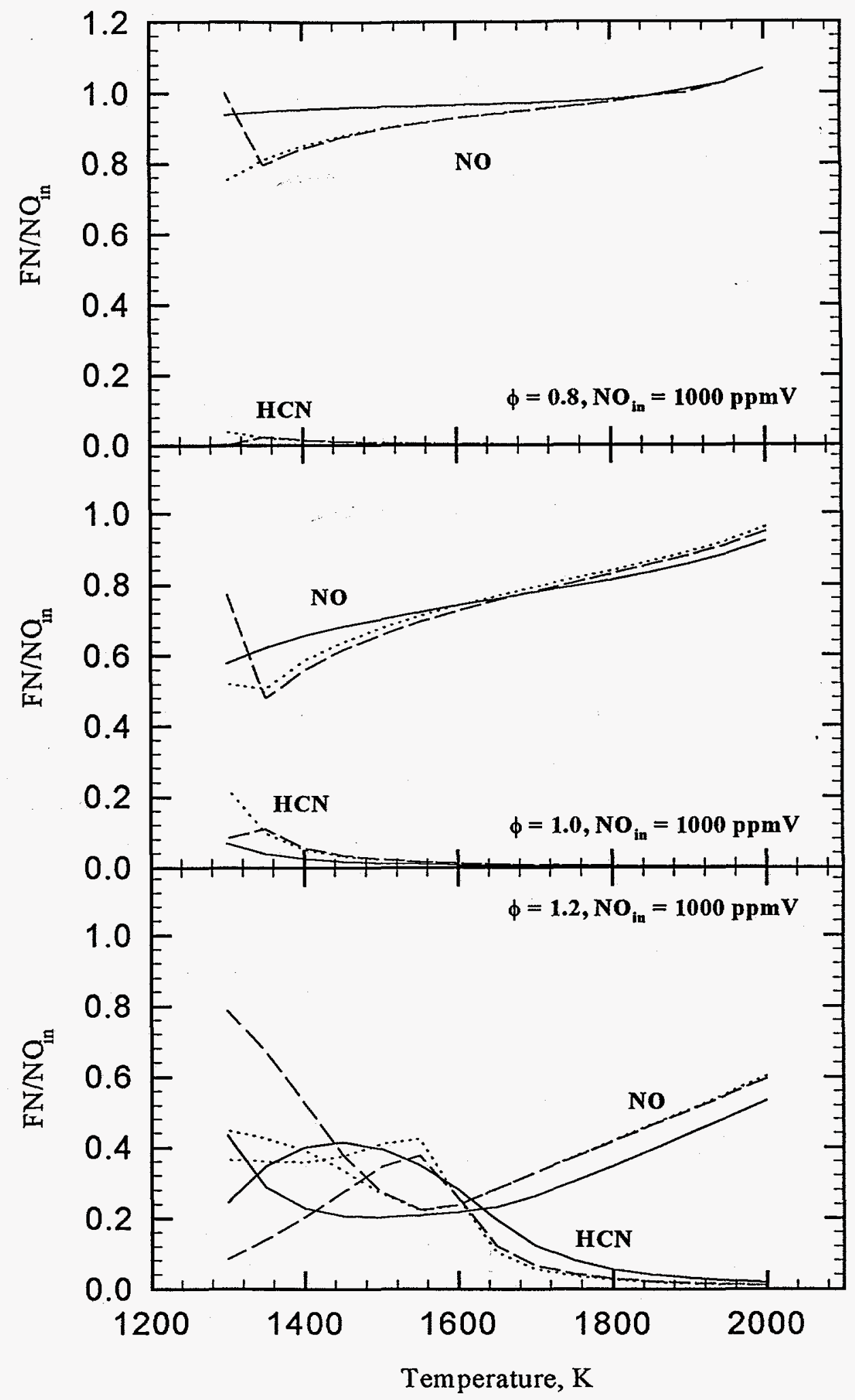

Figure 5: Methane-air combustion at a constant residence time of $10^{-2} \mathrm{~s}$. Line symbols are the same as above. Molar ratios are plotted, where FN indicates the corresponding species. 


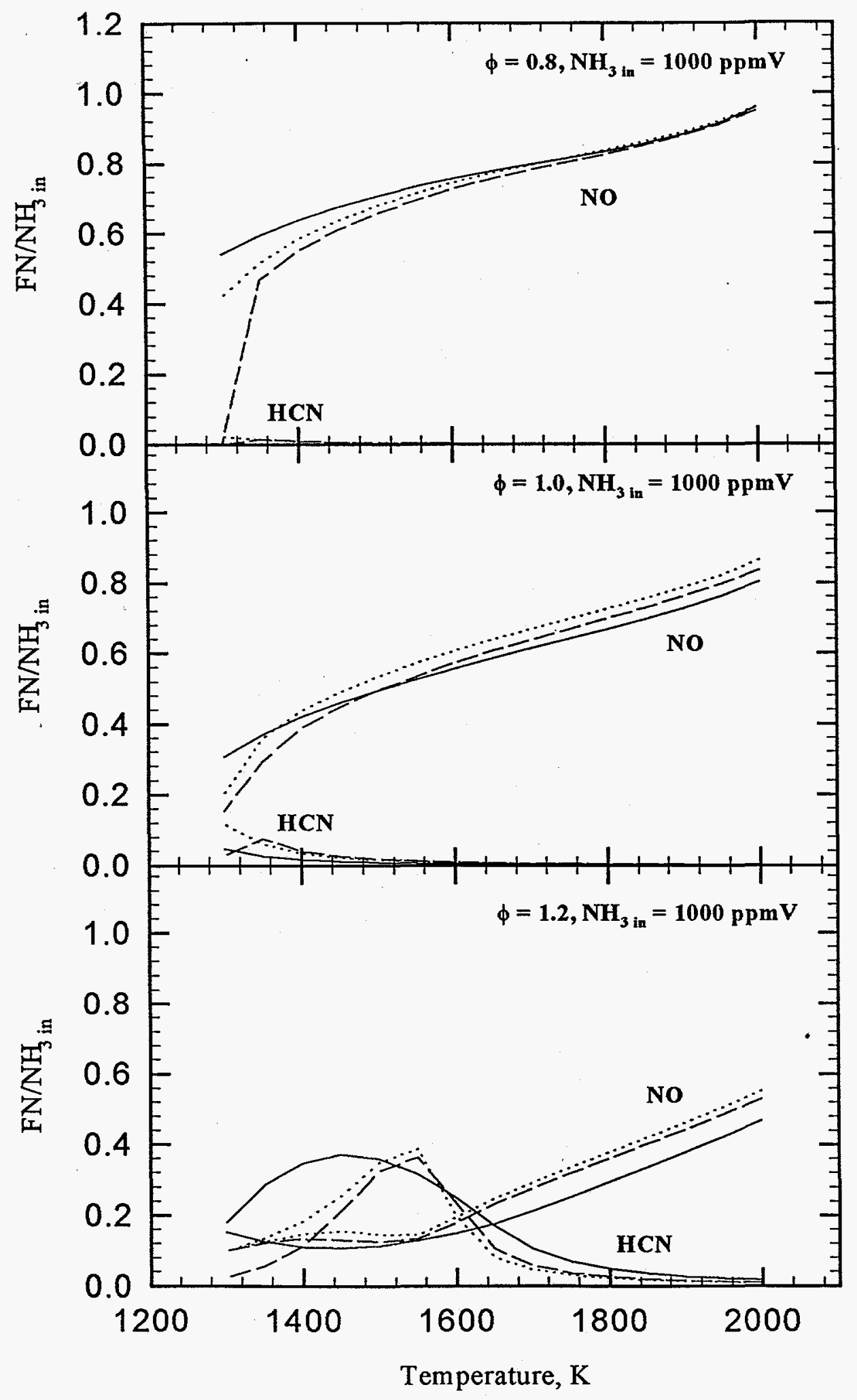

Figure 6: Methane-air combustion at a constant residence time of $10^{-2} \mathrm{~s}$. Line symbols are the same as above. Molar ratios are plotted, where FN indicates the corresponding species. 